\title{
Photosynthesis and growth of young "Niágara Branca" vines (Vitis labrusca L.) cultivated in soil with high levels of copper and liming
}

\author{
Daniel José Rosa ${ }^{1, \text { a }}$, Vítor Gabriel Ambrosini ${ }^{2}$, Alex Basso ${ }^{3}$, Marcelo Borghezan ${ }^{4}$, Gustavo Bruneto ${ }^{5}$, and Rosete \\ Pescador $^{6}$ \\ ${ }^{1}$ Agronomist, Masters student, Post-graduation Program in Plant Genetic Resources, Santa Catarina Federal University, \\ Rod. Admar Gonzaga, 1346, CEP 88034-001, Florianópolis, SC, Brazil \\ ${ }^{2}$ Agronomist, Masters student, Post-graduation Program in Agroecosystems, Santa Catarina Federal University, Rod. \\ Admar Gonzaga, 1346, CEP 88034-001, Florianópolis, SC, Brazil \\ ${ }^{3}$ Bioprocess and Biotechnology Engineer, Masters student, Post-graduation Program in Agroecosystems, Santa Catarina \\ Federal University, Rod. Admar Gonzaga, 1346, CEP 88034-001, Florianópolis, SC, Brazil \\ ${ }^{4}$ Agronomist, Postdoc student, Santa Catarina Federal University, Rod. Admar Gonzaga, 1346, CEP 88034-001, \\ Florianópolis, SC, Brazil \\ ${ }^{5}$ Agronomist, Postdoc, Professor, Santa Maria Federal University, Campus Universitário, CEP 97105-900, Santa Maria, \\ RS, Brazil \\ ${ }^{6}$ Agronomist, Ph.D, Professor, Post-graduation Program in Plant Genetic Resources, Santa Catarina Federal University, \\ Florianópolis, SC, Brazil
}

\begin{abstract}
The objective of this study was to evaluate the photosynthetic response and growth of young grape "Niagara Branca" vines grown in soil with high content of $\mathrm{Cu}$ and liming. The experiment was conducted in controlled environment with soil subjected to three levels of liming, with $0,1.5$ and $3.0 \mathrm{Mg} \mathrm{ha}^{-1}$ of lime. The effect of additional $50 \mathrm{mg} \mathrm{kg}^{-1} \mathrm{Cu}$ in half of soil treatments was evaluated. The $\mathrm{CO}_{2}$ measurements, assimilation rate, stomatal conductance and transpiration were carried out in the tenth cultivation week using the IRGA equipment (Infrared Gaz Analyzer). Plant height, fresh weight and dry weight, concentration of chlorophyll $\mathrm{a}$, chlorophyll b, total chlorophyll, and carotenoids were measured. For most variables, the $\mathrm{Cu}$ had damaging effect on 0 and $1.5 \mathrm{Mg} \mathrm{ha}^{-1}$ liming treatments however, there was no significant damage in the $3.0 \mathrm{Mg} \mathrm{ha}^{-1}$ treatment. Rates of $\mathrm{CO}_{2}$ assimilation, stomatal conductance, and transpiration were increased with the addition of $50 \mathrm{mg} \mathrm{kg}^{-1} \mathrm{Cu}$. Liming to raise the $\mathrm{pH}$ of the soil is an effective practice to reduce the effects of $\mathrm{Cu}$ toxicity in young "Niagara Branca" grape vines.
\end{abstract}

\section{Introduction}

Young "Niagara Branca" grape vines (Vitis labrusca) are routinely subjected to successive applications of fungicides and copper $(\mathrm{Cu})$-based Bordeux mixture for preventive control of foliar fungal diseases. Residual $\mathrm{Cu}$ can accumulate in soils after continuous application, increasing the available form of the element $[3,5]$.

$\mathrm{Cu}$ is an essential to the growth and development of plants micronutrient, but when the soil contains high concentrations, the amount absorbed by plants can be excessive and cause decreased concentrations of photosynthetic pigments, such as chlorophyll and carotenoids, which are responsible for the conversion of light into chemical energy in the form of NADPH and ATP with the releasing $\mathrm{O}_{2}$ [4]. However, impairment of the photosynthetic efficiency of plants results in reduced growth. Therefore, analysis of $\mathrm{Cu}$ concentrations becomes

\footnotetext{
${ }^{a}$ Corresponding author: danielrosa.agro@gmail.com
}

a necessary strategy to mitigate the toxic effects of $\mathrm{Cu}$ to young vines.

When the $\mathrm{pH}$ of the soil is low, $\mathrm{Cu}$ forms are available in greater amounts in soil [1] and therefore, the use of lime for its repair may be an important tool to reduce the availability of the element in the soil, and hence its uptake by plants. Therefore, the application of lime to raise the $\mathrm{pH}$ can be an important strategy to reduce the toxicity of $\mathrm{Cu}$ to plants.

The study aimed to evaluate the photosynthetic response and growth of young "Niágara Banca" vines, grown in soil with high content of $\mathrm{Cu}$ and liming levels.

\section{Materials and methods}

The experiment was conducted at Federal University of Santa Catarina-SC, in a controlled environment room at $25 \pm 2{ }^{\circ} \mathrm{C}$ with a $16 \mathrm{~h}$ light day $^{-1}$ photoperiod with photosynthetically active radiation of $200 \mu \mathrm{mol}$ photon $\mathrm{m}^{2} \mathrm{~s}^{-1} \pm 10$ using seedlings produced by in vitro propagation, after about 60 days of acclimatization. The

This is an Open Access article distributed under the terms of the Creative Commons Attribution License 4.0, which permits unrestricted use, distribution, and reproduction in any medium, provided the original work is properly cited. 
Table 1. Fresh weight and dry weight (g) of shoots of "Niágara Branca" seedlings grown in soil with different levels of lime and copper concentrations.

\begin{tabular}{cccc|ccc}
\hline & \multicolumn{3}{c|}{ Fresh weigth of aerial } & \multicolumn{3}{c}{ Dry weigth of aerial } \\
\cline { 2 - 7 } & $\mathrm{Cu} \mathrm{0}$ & $\mathrm{Cu} 50$ & Average & $\mathrm{Cu} \mathrm{0}$ & $\mathrm{Cu} 50$ & Average \\
\hline Liming 1 & $6,04 \mathrm{aA}$ & $4,00 \mathrm{bB}$ & $5,02 \mathrm{~b}$ & $2,14 \mathrm{aA}$ & $1,48 \mathrm{bB}$ & $1,81 \mathrm{~b}$ \\
Liming 2 & $6,53 \mathrm{aA}$ & $4,61 \mathrm{bB}$ & $5,57 \mathrm{ab}$ & $2,35 \mathrm{aA}$ & $1,69 \mathrm{bAB}$ & $2,02 \mathrm{ab}$ \\
Liming 3 & $6,34 \mathrm{aA}$ & $5,93 \mathrm{aA}$ & $6,13 \mathrm{a}$ & $2,15 \mathrm{aA}$ & $1,95 \mathrm{aA}$ & $2,05 \mathrm{a}$ \\
Average & $6,30 \mathrm{~A}$ & $4,85 \mathrm{~B}$ & & $2,21 \mathrm{~A}$ & $1,71 \mathrm{~B}$ & \\
\hline $\mathrm{CV}(\%)$ & \multicolumn{3}{c}{11,33} & & \multicolumn{3}{c}{11,58} \\
\hline
\end{tabular}

Means followed by different lowercase letters in the column differ by Tukey test at 5\% probability of error for the liming factor. Means followed by different capital letters in the line differ by Tukey test (5\%) for $\mathrm{Cu}$ factor.

soil $0-20 \mathrm{~cm}$ from the border was not subjected to anthropic application. Then, lime was applied at doses of $0,1.5$ and $3.0 \mathrm{Mg} \mathrm{ha}^{-1}$ to obtain the values of $\mathrm{pH} 5.2$; 6.0 and 7.0, with lime termed 1, 2 and 3 respectively. Limestone $\left(\mathrm{MgCO}_{3}\right.$ and $\left.\mathrm{CaCO}_{3}\right)$ PA (PRNT 100\%), $\mathrm{Ca}: \mathrm{Mg}$ of 2:1 was used. After incubation of the soil, the $\mathrm{pH}$ of the treatment was 4.5; 5.5 and 6.2. Half of the soil received $50 \mathrm{mg} \mathrm{kg}^{-1} \mathrm{Cu}$. The experimental design was a randomized block design with six replications in a $3 \times 2$ factorial. Each experimental unit consisted of an allocated plant in a "rhizobox" vessel containing $1.2 \mathrm{~kg}$ of plant soil.

$\mathrm{CO}_{2}$ measurements, assimilation rate, stomatal conductance and transpiration were carried out in the tenth cultivation week in time from 10 to 12 using the IRGA equipment (Infrared Gaz Analyzer) model Li6140XT under a closed system with $380 \mathrm{ppm} \mathrm{CO}_{2}$ and photosynthetic active radiation of $1000 \mu \mathrm{mol}$ photon $\mathrm{m}^{2} \mathrm{~s}^{-1}$ and leaf area of $6 \mathrm{~cm}^{2}$. The plant height was measured using a ruler.

At the end of the experiment, the plants were segmented, weighed and dried at $65^{\circ} \mathrm{C}$ until constant mass and shoot biomass was determined with a precision balance. The concentration of chlorophyll a, b, total and carotenoid was determined by the dimethylsulfoxide (DMSO) method, using $100 \mathrm{mg}$ of foliar tissue and incubated in a water bath with $7 \mathrm{~mL}$ DMSO at $65^{\circ} \mathrm{C}$ for two hours without maceration. After filtering, the total volume was adjusted to $10 \mathrm{~mL}$. The values obtained by spectrometry were used in equations Wellburn (1994) being data expressed in $\mu \mathrm{g} \mathrm{mL}$ : chlorophyll a $=[12.19 *(\mathrm{~A} 665)-3.45 *(\mathrm{~A} 649)]$; chlorophyll $\mathrm{b}=[21,99 *(\mathrm{~A} 649)-5.32 *(\mathrm{~A} 665)]$. The total chlorophyll content was determined from the sum of $\mathrm{Chl}$ a and $\mathrm{Chl} b$. The content of carotenoids was estimated from the formula: total carotenoids $=[1.000 *(\mathrm{~A} 480)-2.14 *(\mathrm{Chla})$ $-70.16 *($ Chlb $)] / 220$.

\section{Results and discussion}

The fresh weight and dry weight of shoots were reduced with the increase of $\mathrm{Cu}$ in soil, with the exception of plants grown in soil with addition of $3.0 \mathrm{Mg} \mathrm{ha}^{-1}$ of lime (Table 1). With this level of liming biomass production of $50 \mathrm{Cu}$ treatment increased significantly and did not differ significantly from the treatments without added $\mathrm{Cu}$. For treatments without the addition of copper, liming factor was not significant. (Table 1). For both treatments, the percentage of dry mass was $35 \%$ of the fresh weight.

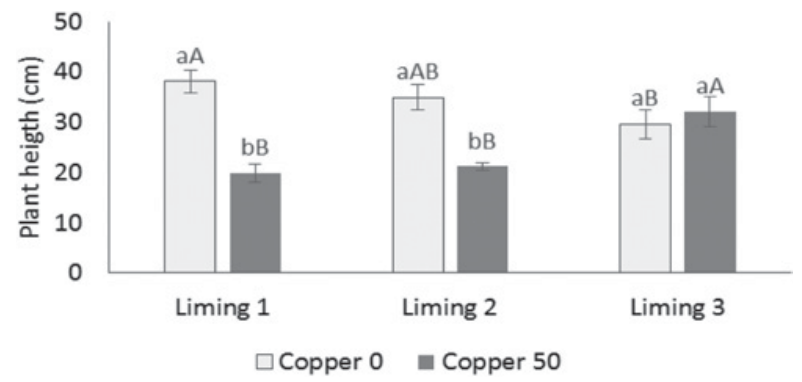

Figure 1. Height $(\mathrm{cm})$ of "Niágara Branca" seedling grown in soil with different levels of lime and copper concentrations. Means followed by the same capital letters factor for copper within the liming factor and lowercase to liming factor in the factor copper do not differ by Tukey test (5\%).

The increment in height (Fig. 1), chlorophyll (Tables 2 e 3) and carotenoids (Table 3 ) of the plants did not differ between the levels of liming for $\mathrm{Cu} 0$. However, for the $\mathrm{Cu} 50$ liming factor was significant for limeing of 0 and $1.5 \mathrm{Mg} \mathrm{ha}^{-1} \mathrm{Cu}$ addition impaired growth and the concentration of the foliar plant pigments. For the liming, of $3 \mathrm{Mg} \mathrm{ha}^{-1}$ average equaled factor for $\mathrm{Cu}$.

Alteration in biomass in height increment and in levels of leaf pigments caused by liming may be a consequence of the reduced availability of $\mathrm{Cu}$ by increasing the $\mathrm{pH}$ of the soil [1]. Furthermore, the increase of calcium and magnesium in the soil by the addition of lime may have been beneficial for young vines because there is a competition for the absorption of these elements and $\mathrm{Cu}$ by plant roots, thereby reducing the content of the trace element in the tissues vegetables [6].

Chlorophyll $a$ was more abundant than chlorophyll $b$ for all treatments (Table 2). The relation chlorophyll $a / b$ showed an average standard of 2.5 , which is consistent with the values and proportions found by [2] who worked with young "Cabernet Sauvignon" grape vines.

The variable content of carotenoids had no effect on the interaction between factors, but it was found that the addition of $\mathrm{Cu}$ reduced its concentration in the leaves of young vines (Table 3 ).

The rate of $\mathrm{CO}_{2}$ assimilation, stomatal conductance and transpiration behaved similarly to each other, and there was superiority of fees for treatments with the addition of $\mathrm{Cu}$ and no difference for the liming factor in both cases (Tables 4 and 5). The reduction in leaf area with addition of copper caused an increase in photosynthetic activity. This effect is possibly related to offset the reduction in 
Table 2. Chlorophyll $a$, chlorophyll $b$ of "Niágara Branca" seedlings grown in soil with different levels of lime and copper concentrations $\left(\mathrm{mg} \mathrm{g}^{-1}\right)$.

\begin{tabular}{cccc|ccc}
\hline & \multicolumn{3}{c|}{ Chlorophyll $a *$} & \multicolumn{3}{c}{ Chlorophyll $b *$} \\
\cline { 2 - 7 } & $\mathrm{Cu} \mathrm{0}$ & $\mathrm{Cu} 50$ & Average & $\mathrm{Cu} 0$ & $\mathrm{Cu} 50$ & Average \\
\hline Liming 1 & $1,39 \mathrm{aA}$ & $1,00 \mathrm{bB}$ & $1,20 \mathrm{ab}$ & $0,50 \mathrm{aB}$ & $0,39 \mathrm{bA}$ & $0,45 \mathrm{a}$ \\
Liming 2 & $1,36 \mathrm{aA}$ & $0,82 \mathrm{bB}$ & $1,09 \mathrm{~b}$ & $0,63 \mathrm{aA}$ & $0,39 \mathrm{bA}$ & $0,51 \mathrm{a}$ \\
Liming 3 & $1,31 \mathrm{aA}$ & $1,24 \mathrm{aA}$ & $1,28 \mathrm{a}$ & $0,49 \mathrm{aB}$ & $0,49 \mathrm{aA}$ & $0,49 \mathrm{a}$ \\
Average & $1,35 \mathrm{~A}$ & $1,02 \mathrm{~B}$ & & $0,54 \mathrm{~A}$ & $0,42 \mathrm{~B}$ & \\
\hline $\mathrm{CV}(\%)$ & \multicolumn{3}{c}{10,96} & & \multicolumn{3}{c}{16,73} \\
\hline
\end{tabular}

Means followed by different lowercase letters in the column differ by Tukey test at $5 \%$ probability of error for the liming factor. Means followed by different capital letters in the line differ for $\mathrm{Cu}$ factor.

Table 3. Total chlorophyll and carotenoids of "Niágara Branca" seedlings grown in soil with different levels of lime and copper concentrations $\left(\mathrm{mg} \mathrm{g}^{-1}\right)$.

\begin{tabular}{lccc|ccc}
\hline & \multicolumn{3}{c|}{ Total chlorophyll* } & \multicolumn{3}{c}{ Carotenoids } \\
& $\mathrm{Cu} 0$ & $\mathrm{Cu} 50$ & Average & $\mathrm{Cu} 0$ & $\mathrm{Cu} 50$ & Average \\
\hline Liming 1 & $1,89 \mathrm{aA}$ & $1,39 \mathrm{bB}$ & $1,64 \mathrm{a}$ & 0,24 & 0,19 & $0,21 \mathrm{a}$ \\
Liming 2 & $1,99 \mathrm{aA}$ & $1,21 \mathrm{bB}$ & $1,60 \mathrm{a}$ & 0,18 & 0,15 & $0,16 \mathrm{~b}$ \\
Liming 3 & $1,81 \mathrm{aA}$ & $1,73 \mathrm{aA}$ & $1,77 \mathrm{a}$ & 0,22 & 0,2 & $0,21 \mathrm{a}$ \\
Average & $1,90 \mathrm{~A}$ & $1,45 \mathrm{~B}$ & & $0,21 \mathrm{~A}$ & $0,18 \mathrm{~B}$ & \\
\hline CV(\%) & \multicolumn{3}{c}{10,06} & & \multicolumn{3}{c}{13,8} \\
\hline
\end{tabular}

Means followed by different lowercase letters in the column differ by Tukey test at $5 \%$ probability of error for the liming factor. Means followed by different capital letters in the line differ for $\mathrm{Cu}$ factor.

Table 4. $\mathrm{CO}_{2}$ assimilation rate and stomatal conductance $\left(\mu \mathrm{mol} \mathrm{m}^{2} \mathrm{~s}^{-1}\right)$ of "Niágara Branca" seedlings grown in soil with different levels of lime and copper concentrations.

\begin{tabular}{ccccccc}
\hline & \multicolumn{3}{c}{$\mathbf{C O}_{2}$ assimilation rate } & \multicolumn{3}{c}{ Stomatal conductance } \\
\cline { 2 - 7 } & $\mathrm{Cu} \mathrm{0}$ & $\mathrm{Cu} \mathrm{50}$ & Average & $\mathrm{Cu} \mathrm{0}$ & $\mathrm{Cu} 50$ & Average \\
\hline Liming 1 & $5,3 \mathrm{Ba}$ & $7,2 \mathrm{Aab}$ & $6,2 \mathrm{a}$ & $0,00359 \mathrm{Ba}$ & $0,00525 \mathrm{Ab}$ & $0,00442 \mathrm{a}$ \\
Liming 2 & $6,6 \mathrm{Aa}$ & $5,4 \mathrm{Ab}$ & $6,0 \mathrm{a}$ & $0,00413 \mathrm{Aa}$ & $0,00365 \mathrm{Aab}$ & $0,00389 \mathrm{a}$ \\
Liming 3 & $5,8 \mathrm{Ba}$ & $8,6 \mathrm{Aa}$ & $7,2 \mathrm{a}$ & $0,00311 \mathrm{Ba}$ & $0,00633 \mathrm{Aa}$ & $0,00472 \mathrm{a}$ \\
Average & $5,9 \mathrm{~B}$ & $7,1 \mathrm{~A}$ & & $0,00361 \mathrm{~B}$ & $0,00507 \mathrm{~A}$ & \\
\hline CV $(\%)$ & \multicolumn{3}{c}{20,61} & & \multicolumn{5}{c}{25,97} \\
\hline
\end{tabular}

Means followed by different lowercase letters in the column differ by Tukey test at $5 \%$ probability of error for the liming factor. Means followed by different capital letters in the line differ for $\mathrm{Cu}$ factor.

Table 5. Transpiration rate $\left(\mu \mathrm{mol} \mathrm{m} \mathrm{s}^{-1}\right)$ "Niágara Branca" seedlings grown in soil with different levels of lime and copper concentrations.

\begin{tabular}{lccc}
\hline & \multicolumn{3}{c}{ Transpiration rate } \\
\cline { 2 - 4 } & $\mathrm{Cu} \mathrm{0}$ & $\mathrm{Cu} 50$ & Average \\
\hline Liming 1 & $0,142 \mathrm{Ba}$ & $0,238 \mathrm{Aa}$ & $0,190 \mathrm{a}$ \\
Liming 2 & $0,189 \mathrm{Aa}$ & $0,153 \mathrm{Ab}$ & $0,171 \mathrm{a}$ \\
Liming 3 & $0,137 \mathrm{Ba}$ & $0,288 \mathrm{Aa}$ & $0,212 \mathrm{a}$ \\
Average & $0,156 \mathrm{~B}$ & $0,226 \mathrm{~A}$ & \\
\hline CV $(\%)$ & \multicolumn{3}{c}{26,56}
\end{tabular}

Means followed by different lowercase letters in the column differ by Tukey test at $5 \%$ probability of error for the liming factor. Means followed by different capital letters in the line differ for $\mathrm{Cu}$ factor.

leaf area, a result of lower seedling development. Similar effects were observed by several authors $[9,10]$ to evaluate the behaviour of plants at different levels of defoliation. These authors suggest that in plants with leaf restriction, the photosynthetic rate is stimulated in organs due to a situation of stress, resulting in increased redistribution of assimilates. This effect is known as photosynthesis offset
[10]. Furthermore, increasing the number of stomata which would allow an increase in gas exchange can occur, but this variable was not assessed.

\section{Conclusion}

The high $\mathrm{Cu}$ contamination in the soil causes harmful effects of the vine physiology. Liming to raise the $\mathrm{pH}$ of the soil is an effective practice to reduce the effects of $\mathrm{Cu}$ toxicity in young "Niágara Branca" vines, coming to neutralize the toxic effect with the application of $3.0 \mathrm{Mg}$ $\mathrm{ha}^{-1}$ for the case study.

\section{References}

[1] Agbenin, J. O., Olojo, L. A. Competitive adsorption of copper and zinc by a Bt horizon of a savanna Alfisol as affected by $\mathrm{pH}$ and selective removal of hydrous oxides and organic matter. Geoderma, Amsterdam, v. 119, n. 1, p. 85-95, mar. (2004)

[2] Amarante, C. V. T., Zanardi, O. D.; Miqueloto, A.; Steffens, C.; Erhart, J.; Almeida, J. Quantificação 
da área e do teor de clorofilas em folhas de plantas jovens de videira 'cabernet sauvignon' mediante métodos não destrutivos. Rev. Brasileira de fruticultura, Jaboticabal - SP, v. 31, n. 3, p. 680-686, Setembro (2009)

[3] Brunetto, G.; Miotto, A.; Ceretta, C. A.; Schmitt, D. E.; Heinzen, J.; Moraes, M. P.; Canton, L.; Tiecher, T. L.; Comin, J. J.; Girotto, E. Mobility of copper and zinc fractions in fungicide amended vineyard sandy soils. Archives of Agronomy and Soil Science (2013)

[4] Cambrollé, J.; García, J. L.; Figueroa, M. E.; Cantos, M. Growth and photosynthetic responses to copper in wild grapevine. Chemosphere Vol. 93, Issue 2, Pages 294-301 September (2013)

[5] Komarek M, Čadková E, Chrastný V, Bordas F, Bollinger J. Contamination of vineyard soils with fungicides: A review of environmental and toxicological aspects. Environ Int. 36:138-151 (2010)

[6] Kopittke, P. M.; Kinraide, T. B.; Wang, P.; Blamey, F. P. C.; Reichman, S. M.; Menzies, M. W. Alleviation of $\mathrm{Cu}$ and $\mathrm{Pb}$ rhizotoxicities in cowpea
(Vigna unguiculata) as related to ion activities at root-cell plasma membrane surface. Environ. Sci. Technol., Iowa, v. 45, n. 11, p. 4966-4973, mai. (2011)

[7] Meuer, E. J. Fundamentos de Química do solo. 4 ed. Porto Alegre: Evangraf, (2012)

[8] Wellburn, A. R. The spectral determination of chlorophylls $a$ and $b$, as well as total carotenoids, using various solvents with spectrophotometers of different resolution. Journal of Plant Physiology, v. 144, p. 307-3013 (1994)

[9] Chanishvili, S.S.; Bafridze, G.S.; Barblishvili, T.F.; Dolidze, M.D. Defoliation, photosynthetic rates, and assimilate transport in grapevine plants. Russian Journal of Plant Physiology, v. 52, n. 4, p. 448-453, 2005

[10] Poni, S.; Casalini, L.; Bernizzoni, F.; Civardi, S.; Intrieri, C. Effects of early defoliation on shoot photosynthesis, yield components, and grape composition. American Journal of Viticulture and Enology, v. 57, n. 4, p. 397-407, 2006 